\title{
CENTURY-OLD TEXTBOOKS IN THE RUTGERS LIBRARY
}

\author{
By Clarence E. Partch
}

One may almost say that during the middle and late nineteenth century William Holmes McGuffey taught the whole of the United States to read. As a part of the nation-wide celebration in bonor of this great educator, $D r$. Clarence E. Partch bas contributed to The Journal the following article in wbicb be tells sometbing of the rôle wbich McGuffey played in American education and of the particular cbaracteristics of bis books. The Rutgers Library is fortunate in baving among the bundreds of old textbooks in its collections original copies of several of the "McGuffey Readers." It was additionally fortunate in this centenary year of McGuffey's birth to receive from Mr. Henry Ford a gift of the wbole set, reprinted in excellent facsimile, of the seven volumes of the "Eclectic Readers."

B ECAUSE of the McGuffey centennial anniversary, interest is centered in the series of McGuffey Readers. In looking at the page-worn books, it seems that the voice of William Holmes McGuffey, whose influence upon public education in this country is still felt today, comes to us across a century to repeat his important message. Just as Horace Mann admonished us that we must educate the souls of children and teach them bow to think, so did William Holmes McGuffey base his philosophy upon the principles of a sound moral education. For three-quarters of a century his Eclectic Readers were the guideposts for pupils in the elementary schools. Thousands of men and women of the past generations, in every walk of life, have acknowledged the influence on their early training received from the McGuffey Readers. Long after they had forgotten the dates of the French and Indian War and the boundary lines of Kentucky, they remembered the wholesome maxims and character building passages of the McGuffey Readers. It is doubtful whether another series of textbooks will ever again influence as large a percentage of our school population over as long a period of time. 
The McGuffey Primer, the first in a series of six readers, was published in 1836 . The series in its entirety forms an important milestone in the educational history of our country. It came into existence to meet a specific need during the early settlement of the Middle West and during the comparatively early stages of our government. A free people cannot be created over night. When once the shackles of oppression are cast off, it is essential that the freed population be imbued with certain fundamental character traits and endowed with basic cultural qualities or it will soon lose its newly acquired privileges. At a time when pioneers were setting out to wrest the middle western lands from the Indians and the Ohio region came into existence, the need for a new education, an education for a free people, was at once apparent. Public schools were organized in Ohio as early as I828. But what of the textbooks of the period? At the turn of the nineteenth century educators readily recognized the need for textbooks and schoolmasters were quick in preparing them. However, the great majority of books contained little original material. The context borrowed both theme and thought from English works and while this material was adaptable for the more gifted students of the so-called "better" families, it held no appeal for and did not meet the needs of children of lower social levels. William Holmes $\mathrm{McGuffey}$ of Ohio was one of the first educators to envisage the new social order that was to emerge from the pioneer population of the Middle West, and he early recognized the need for a new textbook that would be more than just another book of facts. It would embody the best of the older and of the contemporary works and would contain enough new and original material to mould the minds and character of a generation to whom would be delegated the responsibility for evolving the new society.

Harvey C. Minnich, Dean Emeritus of Miami University and Curator of the McGuffey Museum, attributes the supremacy of the McGuffey Readers to the following eight factors: ${ }^{1}$

\footnotetext{
${ }^{1}$ Harvey C. Minnich, William Holmes McGuffey and His Readers (New York: American Book Company, 1936).
} 


\section{Change in metbod of teacbing beginners to read}

The McGuffey Primer "eliminated spelling as a primary unit of mastery prior to the reading step." Instead, reading was correlated with and supplemented by spelling.

The Third and Fourth Readers placed chief emphasis on elocution since at that time the goal of all higher education was preparation for law or the ministry. McGuffey himself was an exponent of eloquence and so in I 844 appeared the Fifth Reader of the series, or the "Rhetorical Guide," for whose preparation Alexander H. McGuffey, a younger brother to William, was responsible.

\section{Emphasis upon enunciation and pronunciation of words}

Sentences were short and simple, ideas followed in sequential order, to hold the interest of the reader, and faulty pronunciation was corrected constantly.

3. Choice and arrangement of material to suit the cbild's mind

"Simplicity with sense, elegance with simplicity, and piety with both," was William Holmes McGuffey's guiding slogan. Material was chosen for its appeal to children and was arranged in a manner that would arouse an interest in reading, create a taste for good literature, and be thoroughly understood by the children. The selections of prose and poetry throughout the series were chosen with meticulous care to illustrate the specific purpose of the individual lesson.

4. Title of the series

Predecessors had heretofore depended largely on sectional names for the titles of their texts, naming them after states and various locals. The Eclectic Series did not confine itself to the limits of any one state or region and its title helped it become universal in appeal. The fact has not been authenticated, but there is sufficient evidence to believe that McGuffey borrowed the term "Eclectic" from Victor Cousin, the French pioneer of "Eclecticism" in philosophy.

5. Standards of social life set forth in the Readers

The Readers served as a coordinating force in unifying the divergent social groups that characterized each section of the 
country west of the Appalachian Mountains. The series contained enough of the Puritan principles to appeal to the New England migrants, enough cultural elements to be acceptable to the aristocracy of Kentucky and enough emphasis upon thrift and economy to satisfy the Germans and the Scots.

\section{Illustrations}

Illustrations were used extensively so that the Primer was a virtual Orbis Pictus, its thirty-two pages containing IOI illustrations. McGuffey appealed to the interest of his young readers by using pictures of children engaged in various activities rather than illustrations of inanimate objects.

\section{Literary merit}

Perhaps the lasting appeal and influence of the Readers are due to their choice selections from the best works in the English language.

Herbert Quick in his autobiography, One Man's Life, sounds a keynote on the influence of the McGuffey Readers in the following paragraph:

And somehow I was inoculated with a little of the virus of good literature. I gained no knowledge that it was anything of the sort. I got not the slightest glimpse into the world of letters as a world. Nobody ever said a word to me about that. I read nothing about it for years and years afterward. But when I did come to read the English classics, I felt as one who meets in after years a charming person with whom he has had a chance encounter on the train. I had already met the gentlemen. I could say as I opened my Shakespeare, my Milton, or my Byron, "Why, don't you remember our meeting away back on the farm in that old book with the front cover torn off? Here's this passage in which the little prince appeals to Hubert de Burgh not to burn out his eyes with those hot irons! I haven't read it yet, but I'll just repeat it from memory. You're no stranger to me. I don't know much of you, but what I do know I know well!'2

\section{Publisbing bouse}

Winthrop B. Smith, a Cincinnati publisher, early realized the merits of the McGuffey Readers and maintained an

${ }^{2}$ ibid., p. 83. 
eminent editorial staff to help in the revision of the books. Much of the success of the series is due to the ingenuity and foresight of the publisher and his staff.

Were the lessons of the McGuffey Readers incorporated into a code of ethics, this code would include training in almost every branch of character building and morals. The $\mathrm{I}, 200$ lessons in the series instilled in the readers love for honesty, obedience and kindness, respect for parents, home and family, and a desire to be thrifty, patriotic and industrious.

To children of the early nineteenth century, the Readers constituted an escape from the gloomy, melancholy literature with which their school days had been surrounded. Practically all juvenile literature of colonial days had dwelled upon the necessity of death and the grave, and children went through school on a diet of morbid tales about the death of infants and the virtue of dying young. Childhood seems to have been enveloped by a sense of guilt and school life devoted to the redemption of self-imposed sins. McGuffey offered his young readers prose and poetry that told of life instead of death, that contained messages of hope and happiness instead of fear and horror, and children were eager to accept his contribution.

Textbooks have always played an important rôle in American education. An examination of the McGuffey series and other early American texts affords an interesting overview of the development of public education in this country. Ample opportunity to evaluate early school books is provided by the Rutgers University Library which contains a collection of more than five hundred texts printed between I $800-1850$, one-fifth bearing publication dates within the first twenty years of the century. 